\title{
REVIEW
}

\section{What Is a Hormone?}

\author{
Luboslav STÁRKA ${ }^{1}$, Michaela DUŠKOVÁ ${ }^{1}$ \\ ${ }^{1}$ Institue of Endocrinology, Prague, Czech Republic
}

Received August 21, 2019

Accepted December 19, 2019

\begin{abstract}
Summary
Starling's original definition of a hormone from 1905 was "a hormone is a substance produced by glands with internal secretion, which serve to carry signals through the blood to target organs". Today, this definition is understood to be lacking, but newer definitions also do not encompass the entire meaning of hormones as specific carriers of information. One main problem is that there is no delineation between hormones and other signaling molecules such as cytokines, growth factors or autacoid compounds. It seems that a precise definition is not even possible, since some cytokines and growth factors, such as the cytokines erythropoietin, lipocalin-2 and asprosin or fibroblast growth factor 23, act as hormones under certain conditions.
\end{abstract}

\section{Key words}

Hormone definition $\bullet$ Cytokine $\bullet$ Growth factors $\bullet$ Erythropoietin $\bullet$ Lipocalin-2 • Asprosin • Fibroblast growth factor 23

\section{Corresponding author}

L. Stárka, Department of Steroids and Proteofactors, Institute of Endocrinology, Národní 8, 11994 Prague 1, Czech Republic. E-mail: Istarka@endo.cz

\section{Introduction}

At the turn of the $20^{\text {th }}$ century, an important medical discipline was formulated that significantly improved our understanding of various organismic regulatory processes - endocrinology. There had been studies on the activities of extracts from the adrenals, thyroid, spleen, and pituitary, as well as knowledge resulting from the loss of these organs. Compounds that had regulatory functions had been called hormones since 1905, when this term was first used in June of that year at the Croonian Lecture for the Royal College of Physicians of London by the physiologist Ernest Henry Starling (1866-1927). In his research on the effects of duodenal secretions on the pancreas, he discovered the compound secretin, which induced an effect even after all nerves were removed from the duodenum, thus showing the signal did not travel through nerves but through the blood. A hormone was thus defined as a compound that is produced in a secretory tissue and transported in the blood circulatory system to target tissues, where they induce functional changes. This concept of a hormone later appeared in textbooks with the formulation: ,a hormone is a substance produced by glands with internal secretion, which serves to carry signals through the blood to target organs". The associated definitions of glands and internal secretion were then "glands with internal secretion produce hormones, which are carried through the body by the circulatory system. They do not secrete to the external system". These definitions were of course circular, and are currently barely satisfactory, with many exceptions. Hormones can be produced in tissues other than specialized glands with internal secretions, and transport to their site of action is not tied to the circulatory system. In plants each cell is capable of producing hormones. Hormones are indeed carriers of information, but there exists a vast array of signaling compounds that we do not consider hormones.

\section{Recent definitions of a hormone}

The imprecise classical definition of a hormone has been modified in newer definitions, for instance from the latest edition of the Encyclopaedia Britanica: „Hormone, an organic substance secreted by plants and 
animals that functions in the regulation of physiological activities and in maintaining homeostasis" (Barrington 2019), or the definition from the Biology Dictionary (2019): „A hormone is a biological compound used by multicellular organisms to organize, coordinate, and control the functions of their cells and tissues. These chemicals can control everything from metabolism to behavior“. Another definition is as follows: „A hormone is any of various internally secreted compounds, as insulin or thyroxine, formed in endocrine glands, that affects the functions of specifically receptive organs or tissues when transported to them by the body fluids" (Dictionary.com 2019). Similar definitions can be found in physiology textbooks, for instance the world-renowned Ganong's Review of Medical Physiology: „Hormones are the soluble messengers of the endocrine system" (Barret et al. 2019). However, considering recent findings even these definitions have many drawbacks. We know that hormones can be produced by tissues other than glands with internal secretion (for instance osteoblasts, adipocytes and kidneys), and that the signaling can occur outside the circulatory (autocrine or paracrine effects, plant and insect hormones). However, the primary difficulty is the delineation between hormones and other factors that carry information in an organism, whether cytokines, growth factors, or autacoid factors. The situation is further complicated by the dual role played by some factors, and recent findings have shown that some cytokines and growth factors have typical hormone-like function.

\section{Signal molecules other than hormones}

Cytokines are a group of smaller signaling proteins, mainly playing a role in the immune response, including interferons, interleukins, lymphokines, chemokines, and tumor necrotizing factors. Growth factors are generally substances or stimuli that influence the growth of an organism or its part. They include mainly a group of proteins that stimulate cellular proliferation and differentiation. Autacoids are biological factors (signaling molecules) that act as local factors, with short-term activity and function close to their site of synthesis. They include molecules such as eicosanoids (prostaglandins, thromboxanes, leukotrienes, lipoxins, resolvins, and eoxins), angiotensin, neurotensin, gaseous hormones (nitrous oxide - NO, nitrogen - N, hydrogen sulfide $-\mathrm{H}_{2} \mathrm{~S}$ ), kinins, histamine, serotonin, endothelins, endocannabinoids, and palmitoylethanolamide.

\section{Differentiating hormones from other signaling molecules}

No clear boundaries exist between hormones and other types of signaling molecules because some cytokines, growth factors and autacoid factors act like typical hormones in certain situations. The cytokine erythropoietin is the main hematopoietic factor and is primarily synthesized in the kidneys. However, erythropoietin and its receptors are also present in various other tissues, and have pleiotropic effects outside the production of blood. While in a hematogenic role this molecule binds to a homodimer receptor, the nonhematogenic activity is regulated through a heterodimeric receptor. Erythropoietin also has anti-apoptotic activity, and has potential neuroprotective, nephroprotective, and cardioprotective roles during ischemia and other tissue damage. It also has function in angiogenesis, neurogenesis, and the immune response. In diabetic patients, erythropoietin lowers hyperglycemia and slows the proliferation of retinopathy. As such, erythropoietin can also be considered a hormone (Jelkman and Wagner 2004, Alnaeeli et al. 2014).

Other examples can be found in several growth factors. Of the 27 known fibroblast growth factors, three are classified and endocrine growth factors (FGF19, FGF21, and FGF23). Fibroblast growth factor 23 (FGF23) produced in bones lowers the reabsorption of phosphate and the production of calcitriol in the kidneys, and lowers the production of parathormone in the parathyroid glands, and as such is an important regulator of calciophosphate metabolism. FGF23 should be considered a hormone that is part of the bone-kidney regulatory axis (ADHR Consortium 2000, Žofková 2015, Žofková 2018). It protects the organism from an excess of vitamin $\mathrm{D}$, and regulates bone mineralization through renal effects on phosphate availability. Defects in the production or secretion of FGF23 lead to imbalances in phosphate homeostasis. Additionally, the cytokine lipocalin-2 inhibits dietary intake through binding to the melanocortin 4 receptor in the hypothalamus (Mosialou et al. 2017), and regulates glucose tolerance, insulin sensitivity and insulin secretion as part of glucose homeostasis (Law et al. 2018). Lipocalin-2 is secreted from various tissues, and it is possible that its function depends on the tissue of origin. Another example may be asprosin, an adipokin, which is an orexigenic hormone signaling hunger and increasing hepatic glucose production and glycemia like ghrelin (Romere et al. 2016). 


\section{Conclusion}

Current definitions of a hormone roughly cover the fundamental aspects of these compounds as signaling molecules necessary for carrying signals to target tissues, but are not generally applicable since they do not delineate them from other types of signaling molecules. This is likely not possible, as some cytokines, growth factors and autacoid factors have the characteristics and functions of hormones under certain circumstances.
Examples include erythropoietin, fibroblast growth factor FGF23, asprosin and lipocalin-2.

\section{Conflict of Interest}

There is no conflict of interest.

\section{Acknowledgements}

Supported by the project MHCZ-DRO (Institute of Endocrinology - EU, 00023761).

\section{References}

ADHR CONSORTIUM: Autosomal dominant hypophosphataemic rickets is associated with mutations in FGF23. Nat Genet 26: 345-348, 2000. https://doi.org/10.1038/81664

ALNAEELI M, RAAKA BM, GAVRILOVA O, TENG R, CHANTURIYA T, NOGUCHI CT: Erythropoietin signaling: a novel regulator of white adipose tissue inflammation during diet-induced obesity. Diabetes 63 : 2415-2431, 2014. https://doi.org/10.2337/db13-0883

BARRET KE, BARMAN SM, YUAN J, BROOKS HL: Ganong's Review of Medical Physiology, 26th Edition, McGraw-Hill Education, 2019.

BARRINGTON EJW: Hormone. Encyclopaedia Britanica 2019.

BIOLOGY DICTIONARY https://biologydictionary.net/ 2019.

DICTIONARY.COM https://www.dictionary.com/2019.

JELKMANN W, WAGNER K: Beneficial and ominous aspects of the pleiotropic action of erythropoietin. Ann Hematol 83: 673-686, 2004. https://doi.org/10.1007/s00277-004-0911-6

LAW IK, XU A, LAM KS, BERGER T, MAK TW, VANHOUTTE PM, LIU JT, SWEENEY G, ZHOU M, YANG B, WANG Y: Lipocalin-2 deficiency attenuates insulin resistance associated with aging and obesity. Diabetes 59: 872-882, 2010. https://doi.org/10.2337/db09-1541

MOSIALOU I, SHIKHEL S, LIU JM, MAURIZI A, LUO N, HE Z, HUANG Y, ZONG H, FRIEDMAN RA, BARASCH J, LANZANO P, DENG L, LEIBEL RL, RUBIN M, NICKOLAS T, CHUNG W, ZELTSER LM, WILLIAMS KW, PESSIN JE, KOUSTENI S: MC4R-dependent suppression of appetite by bone-derived lipocalin 2. Nature 543: 385-390, 2017. https://doi.org/10.1038/nature21697

ROMERE C, DUERRSCHMID C, BOURNAT J, CONSTABLE P, JAIN M, XIA F, SAHA PK, DEL SOLAR M, ZHU B, YORK B, SARKAR P, RENDON DA, GABER MW, LEMAIRE SA, COSELLI JS, MILEWICZ DM, SUTTON VR, BUTTE NF, MOORE DD, CHOPRA AR: Asprosin, a fasting-Induced glucogenic protein hormone. Cell 165: 566-579, 2016. https://doi.org/10.1016/j.cell.2016.02.063

ŽOFKOVÁ I: Bone tissue as a systemic endocrine regulator. Physiol Res 64: 439-445, 2015. https://doi.org/10.33549/physiolres.932900

ZOFKOVA I: Involvement of bone in systemic endocrine regulation. Physiol Res 67: 669-677, 2018. https://doi.org/10.33549/physiolres.933843 